\title{
Taxonomy of the spring dwelling amphipod Synurella ambulans (Crustacea: Crangonyctidae) in West Russia: with notes on its distribution and ecology
}

\author{
Dmitry SIDOROV ${ }^{1, *} \&$ Dmitry PALATOV ${ }^{2}$ \\ ${ }^{1}$ Department of Zoology, Institute of Biology and Soil Science FEB RAS, 100-let Vladivostoku Av. \\ 159, Vladivostok 690022, Russia. E-mail: sidorov@biosoil.ru \\ urn:1sid:zoobank.org:author:55C1264F-67C0-4C3F-8E6B-ECE1E821457B \\ ${ }^{2}$ Department of Hydrobiology, Moscow State University, Leninskie Gory 1/12, Moscow 119991, \\ Russia. E-mail: triops@yandex.ru \\ urn:1sid:zoobank.org:author:25BBE8A0-81C4-4B42-859A-3A7BA3EE3C0E \\ * Corresponding author: E-mail: sidorov@,biosoil.ru
}

\begin{abstract}
This study deals with taxonomic problems of the semi-subterranean crangonyctid amphipod Synurella ambulans (F. Müller, 1846), well-known from various freshwater habitats in Europe. The taxonomy of the species $S$. ambulans and the generic diagnosis for the genus Synurella are revised. A new synonymy is proposed: Synurella ambulans (F. Müller, 1846) = Synurella ambulans meschtscherica Borutzky, 1929, syn. nov. The affinity with the related groups, distribution and ecology of the species are examined.
\end{abstract}

Key words. Amphipoda, Crangonyctidae, Synurella ambulans, stygophile, distribution, ecology, springs.

Sidorov D. \& Palatov D. 2012. Taxonomy of the spring dwelling amphipod Synurella ambulans (Crustacea: Crangonyctidae) in West Russia: with notes on its distribution and ecology. European Journal of Taxonomy 23: 1-19. http://dx.doi.org/10.5852/ejt.2012.23

\section{Introduction}

The amphipod genus Synurella Wrześniowski, 1877 is stygophile, but lacking typical stygomorphic features such as anophthalmy, depigmentation and reduced fecundity (the females normally produce no less than 11-20 small-sized eggs). Synurella occurs in semi-subterranean freshwaters and coastal plain brackish habitats throughout the Holarctic region (Karaman 1974a, 1990; Barnard \& Barnard 1983). To date, approximately 19 species of Synurella have been described, including 6 from Russia. The geographical records of Synurella in western Russia are confined to three described species: S. donensis Martynov, 1919 (springs of Rostov-on-Don vicinity), S. derzhavini Behning, 1928 (wells of Saratov vicinity) and S. meschtscherica (Borutzky, 1929) (springs and spring-runs of Meschtschera).

The goal of our study was to examine taxonomic boundaries between $S$. ambulans and $S$. meschtscherica. Some authors previously had doubts about the validity of S. meschtscherica (see Karaman 1974a) and 
assumed it was a junior synonym of $S$. ambulans, because of the lack of clear differences between these taxa. However, it was thus far never formally synonymized. It should be noted, that initially S. meschtscherica was reported by Borutzky (1927) under the name $S$. ambulans, who then later described it as a subspecies of that species (Borutzky 1929). Birstein (1948) provisionally evaluated the status of $S$. ambulans meschtscherica and suggested that it deserved species status. However, this was done without sufficient argumentation.

The taxonomy of the genus is confusing. Some forms of the large species-complex $S$. ambulans are considered distinct species by some researchers, whereas other workers only rank them as subspecies or consider them as local forms. Moreover, poorly known nominal species such as $S$. donensis, S. ambulans taurica Martynov, 1931 and S. philareti Birstein, 1948 may simply be aberrant forms of other, betterknown, species. Consequently, the number of species to be included in the genus is uncertain. The species S. ambulans was described as Gammarus ambulans by Friedrich Müller (1846) from ditches at Greifswald in Mecklenburg-Vorpommern (N Germany) (Müller 1846). It has been suggested previously that the species is extremely polymorphic and widespread in Europe and Asia Minor (Ruffo 1974; Karaman 1974a, 2003; Nesemann 1993; Muskó 1994; Kontschán 2001; Pezzoli 2010). However, the morphological variability of the species was interpreted too liberally by the former authors and without good reasons. As a consequence of this incomplete taxonomic knowledge, erroneous conclusions about species origin and distribution were formulated. Since the recent discovery of $S$. ambulans in the Black Sea area (Ketelaars 2004), Ukraine (Alexandrov et al. 2007) and in the Belgian province of WestFlanders (Boets et al. 2010), it was assigned to a group of Ponto-Caspian invaders, although there is no sound evidence for this assumption.

Some authors have considered integrating the genus Synurella into the genus Stygobromus, owing to the lack of clear morphological and geographical boundaries between these groups (Birstein 1948; Karaman 1974a, 1974b), or directly united them (Barnard \& Barnard 1983). However, some researchers have expressed the opposite view (Holsinger 1977; Bousfield 1977). In our opinion, significant morphological differences between these genera are primarily observed in the general body morphology. Moreover, the genus Synurella is not monophyletic according to Martynov (1931), who assigned all the Far EasternSiberian and one Alaskan species to the subgenus Eosynurella. The latter group differs markedly from the European taxa, except for Synurella dershavini Behning, 1928 and from the North American Synurella, by the pear-shaped gnathopod 2 propodi and the structure of uropod 3 with a strongly reduced terminal segment. It is possible that the biogeography of the genera Synurella and Stygobromus cannot be explained by a simplified barrier-insulation approach proposed by several authors (Birstein 1948; Karaman 1974a, 1974b), but should apparently be explained by isolation through the existence of ancient seas, straits, and by evolutionary differences.

Synurella meschtscherica from the Meschtschera Lowland is now formally considered a junior synonym of $S$. ambulans. In our study we examined samples from the topotype locality of S. meschtscherica. We further include detailed distributional information based on morphological comparison of material from scattered localities in West Russia.

\section{Material and Methods}

\section{Taxonomic sampling}

The specimens of $S$. meschtscherica were collected and studied from an extensive territory on the East European Plain (Fig. 1), ranging from the Baltic Sea basin (Pskov administrative area) to the Meschtschera Lowland in the east (Moscow, Ryazan, Vladimir areas) and in the south to the Central Russian Upland in the Oka River basin (Kaluga area) as far as the upper part of the Dniepr River basin (Bryansk area). The 
comprehensive collection of specimens was carried out mostly by the second author using a common hand net. The samples were preserved in $80 \%$ ethanol and are kept at the Institute of Biology and Soil Science (Vladivostok). Preserved material of S. ambulans at the Museum of Naturkunde (Berlin), collected and determined by M.L. Zettler from Kassow near Rostock (Mecklenburg-Vorpommern, Germany), was also used in this study for comparison of two species.

\section{Morphology}

All relevant morphological structures were examined and measured. To measure the body length, more precisely the distance along the dorsal side of the body from the base of the first antenna to the base of

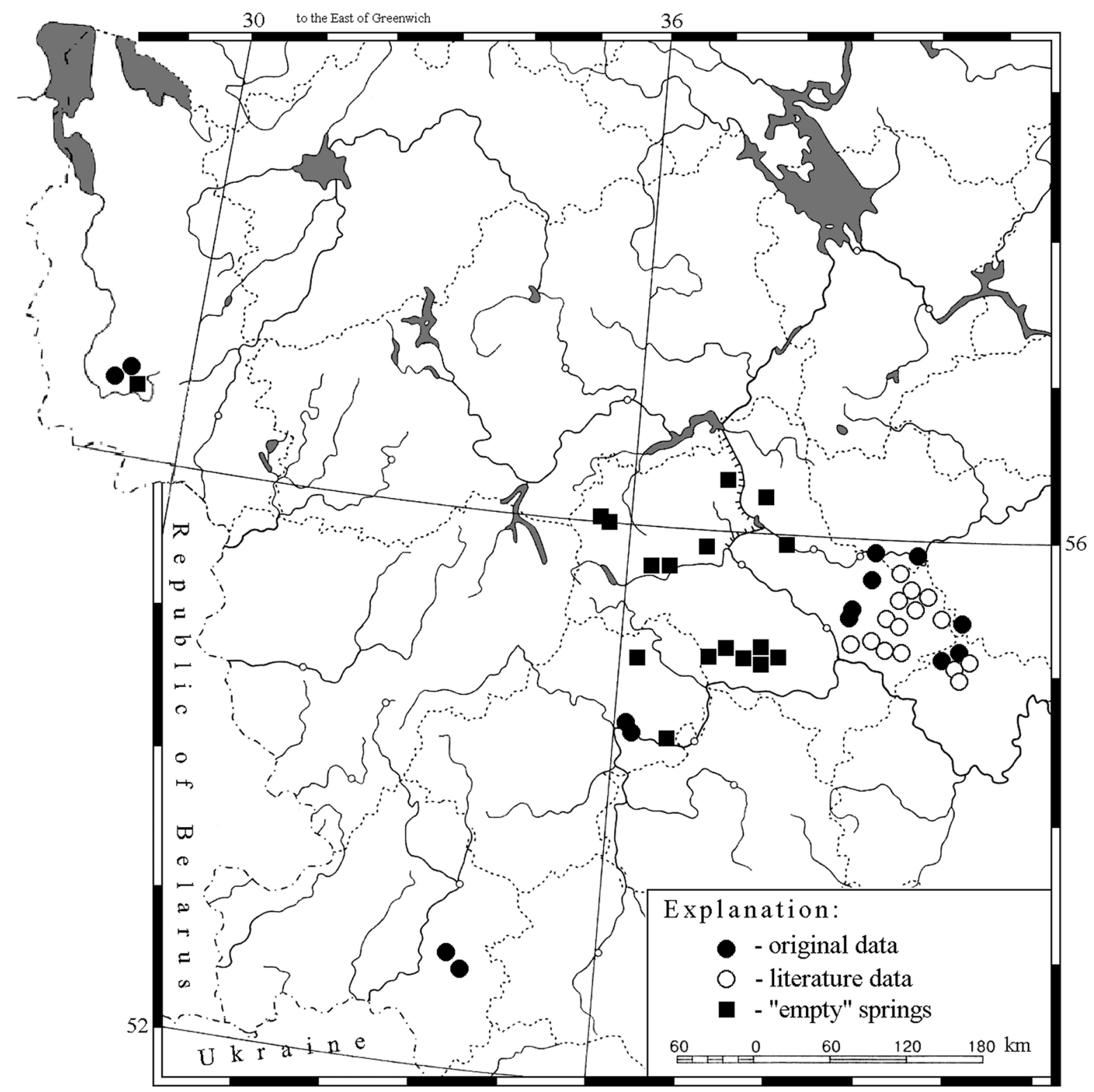

Fig. 1. Map indicating the geographic distribution of Synurella ambulans (F. Müller, 1846) in western Russia. Legend: "empty" springs display undisturbed springs with a rich crenophilous fauna without $S$. ambulans. Literature data: Borutzky (1929), Chertoprud (2006a, 2006b). Source: Blank Mapping Tools, Moscow (2009). 
the telson, the specimen was held in a ventro-dorsal position. A Lomo MBS-9 stereomicroscope with a scaled micrometer eyepiece was used to make this measurement and appendages were drawn using a Carl Zeiss NU-2 compound microscope equipped with a drawing device as modified by Gorodkov (1961). The permanent preparations were made using polyvinyl lactophenol (PVL) and a methylene blue staining solution. A lens adapter LSN-23D by Zarf Enterprises for Nikon CoolPix 995 was used for digital photomicrography of the lateral cephalic lobes and appendages.

The term "defining angle" of the gnathopod propodi refers to the angle formed at the end of the palm and beginning of the posterior margin or the point at which the tip of the dactylus closes on the propodus (see Holsinger 1974). The nomenclature for setal patterns on segment 3 of the mandibular palp follows the standard introduced by Karaman (1970). The descriptive terminology follows a classification system based on the homology concept proposed by Watling (1989). The following description was generated from a DELTA database (Dallwitz 2005) for the crangonyctid genera and species of the world.

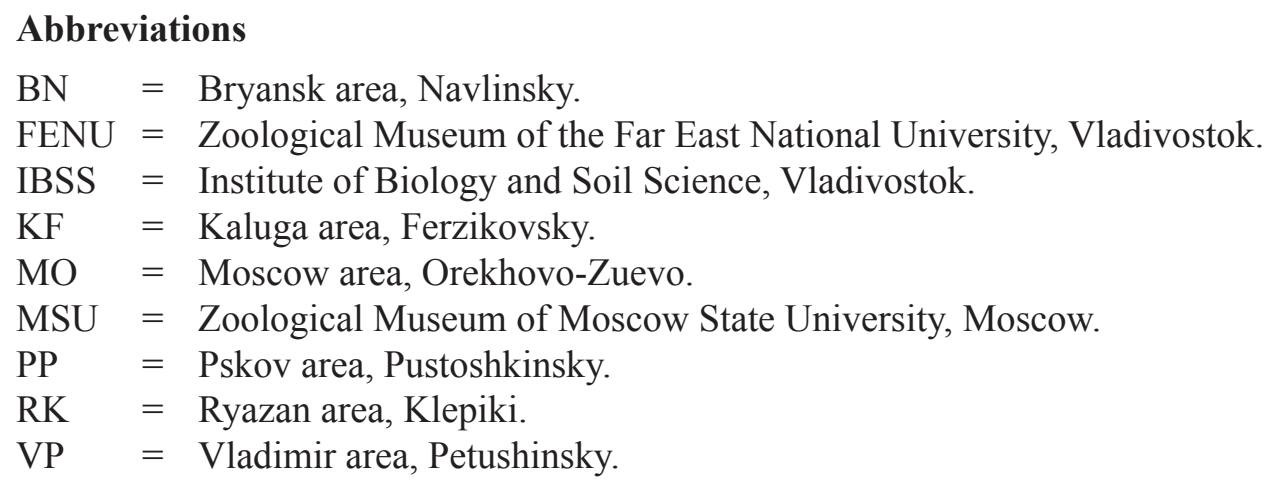

\section{Results}

Taxonomy

Order Amphipoda Latreille, 1818

Family Crangonyctidae Bousfield, 1973

Genus Synurella Wrześniowski, 1877

Synurella Wrześniowski, 1877: 403.

Goplana Wrześniowski, 1879: 299.

Boruta Wrześniowski, 1888: 44.

Eosynurella Martynov, 1931: 531.

Diasynurella Behning, 1940: 43.

\section{Type species}

Gammarus ambulans F. Müller, 1846 (= Synurella ambulans (F. Müller, 1846) designated by Wrześniowski (1877)).

\section{Revised diagnosis (related to sub-family group 1 sensu Bousfield 1977: 302)}

Closely allied with Stygobromus Cope, 1872, but with the following characteristic features: head, lateral cephalic lobe broadly rounded without inferior sinus (except Synurella osellai); antenna 2 of male with paddle-shaped calceoli; gnathopod 1 propodi sub-quadrate; gnathopod 2 propodi with well-developed posterior margins, propodi always larger than the same of gnathopod 1; coxal plates 1-3 deep, much longer than broad; coxal plate 4 deep, with excavation; urosomites partially or entirely fused; telson apical margin distinctly notched or lobate; oöstegites 2-5 large, ovoid. 


\section{Remarks}

In our opinion, the Crimean form Synurella ambulans taurica Martynov, 1931, with a slightly extended basipodite of pereopod 7, is related to the southern species complex of $S$. intermedia and $S$. tenebrarum rather than to the nominative species. However, owing to the poor description it is difficult to reach a definite conclusion.

\section{Synurella ambulans (F. Müller, 1846) (sensu stricto)}

Figs 2-9

Gammarus ambulans F. Müller, 1846: 296, Taf. 10, figs A-C (original description).

Synurella ambulans Stebbing, 1906: 369.

Synurella polonica Wrześniowski, 1877: 403.

Synurella ambulans meschtscherica Borutzky, 1929: 30, figs 1-17, syn. nov.

Synurella meschtscherica Birstein, 1948: 70.

Stygobromus ambulans Barnard, 1983: 438.

Stygobromus meschtschericus Barnard, 1983: 440.

Synurella ambulans - Schäferna 1922: 57, tab. 1 (10), tab. 2 (1-4), text-figs 26-29. - Borutzky 1927: 63. - Schellenberg 1942: 85, Fig. 66.

Synurella polonica - Stebbing 1906: 369. — Jarocki \& Krzysik 1924: 555.

Synurella ambulans meschtscherica - Straškraba 1962: 132.

Synurella meschtscherica - Barnard 1958: 75. — Straškraba 1967: 208. — Karaman 1974a: 124.

Stygobromus meschtschericus - Starobogatov 1995: 192. — Chertoprud 2006a: 19; 2006b: 382.

\section{Diagnosis}

Medium-sized species with marked secondary sexual dimorphism. Body pigmented. Gnathopod 2 larger than gnathopod 1. Pereopod 6 longer than pereopod 7. Pereopod 7 basis without distinct posterior lobe. Coxal gills on pereopods 2-7, gill 7 very small. Sternal gills arrangement as following: pereonite 2 (-2-), pereonite $3(-2-)$, pereonite $6(1-1)$, pereonite $7(1-1)$, pleonite 1 (1-1). Brood plates 2-5 (oöstegites) rather broad, with long marginal setae. Body length $3.5-6.0 \mathrm{~mm}($ ( + $), 3.0-4.5 \mathrm{~mm}\left({ }^{\Uparrow}\right)$.

A distinctive feature of this species is a well-marked broad yellowish spot (Fig. 2A) located on the dorsal surface of the head between eyes. The spot is discernible only in living animals.

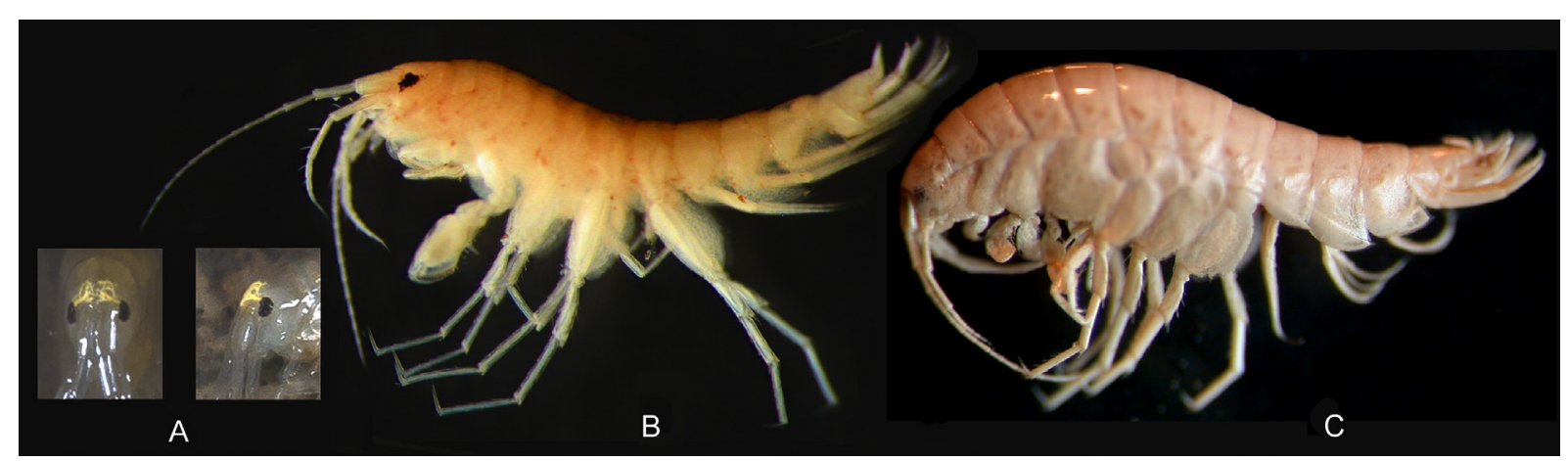

Fig. 2A-C. Synurella ambulans (F. Müller, 1846). A. Yellow spot on the dorsal surface of the head of

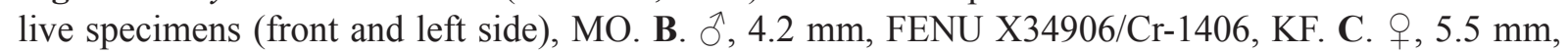
FENU X34906/Cr-1406, BN, left side (preserved specimens). 


\section{Material examined}

GERMANY. All specimens $(3 q+, 1$ ) completely dissected and mounted on a single slide per number: [MSU Mb-1146] + (oöstegites developed, setose) $5.7 \mathrm{~mm}$ and $ð 4.2 \mathrm{~mm}$, [FENU X34906/Cr-1406] + (oöstegites developed, setose) $5.5 \mathrm{~mm}$ and $q$ (oöstegites developed, setose) $5.2 \mathrm{~mm}$. MecklenburgVorpommern, Kassow (5387’76.3”N 1207'67.2”E), 21 May 1997, collected by M. Zettler.

RUSSIA. All specimens completely dissected and mounted on a single slide [FENU X34906/Cr-1406],

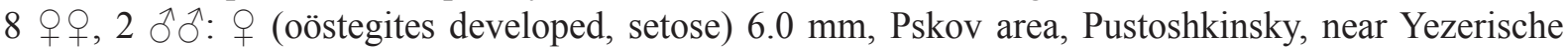

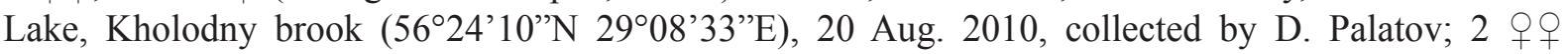
(oöstegites developed, setose) $3.5 \mathrm{~mm}$ and $5.5 \mathrm{~mm}$, Bryansk area, Navlinsky, Desna River basin, near Partizanskoye, pond ( $52^{\circ} 45^{\prime} 77^{\prime}$ N $34^{\circ} 22^{\prime} 72^{\prime}$ 'E), 17 Sep. 2009, collected by D. Palatov; 우 (oöstegites developed, non-setose) $5.5 \mathrm{~mm}$ and $\odot$ (oöstegites developed, setose) $4.0 \mathrm{~mm}$, Kaluga area, Ferzikovsky,

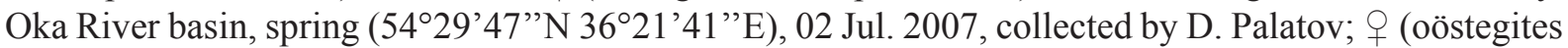
developed, non-setose) $5.2 \mathrm{~mm}$ and $\lesssim 4.5 \mathrm{~mm}$, Moscow area, Orekhovo-Zuevo, $\sim 3.5 \mathrm{~km}$ E of Voinovo,

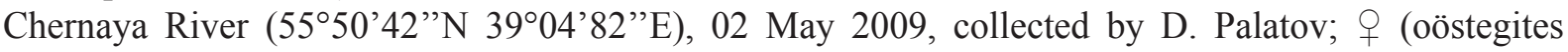

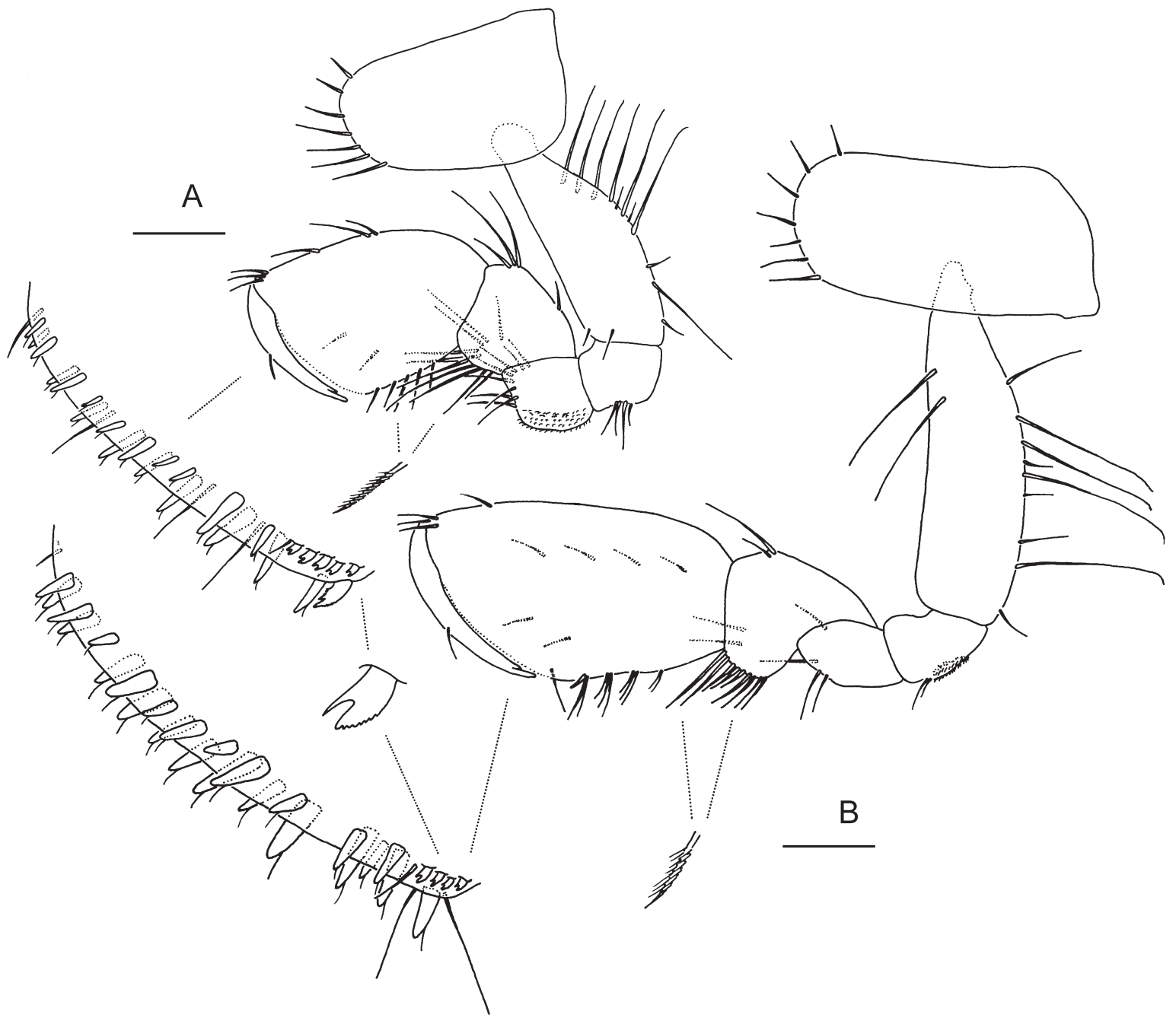

Fig. 3A-B. Synurella ambulans (F. Müller, 1846), ô, 4.5 mm, FENU X34906/Cr-1406, MO. A. Gnathopod 1. B. Gnathopod 2. Scale bars $0.2 \mathrm{~mm}$. 


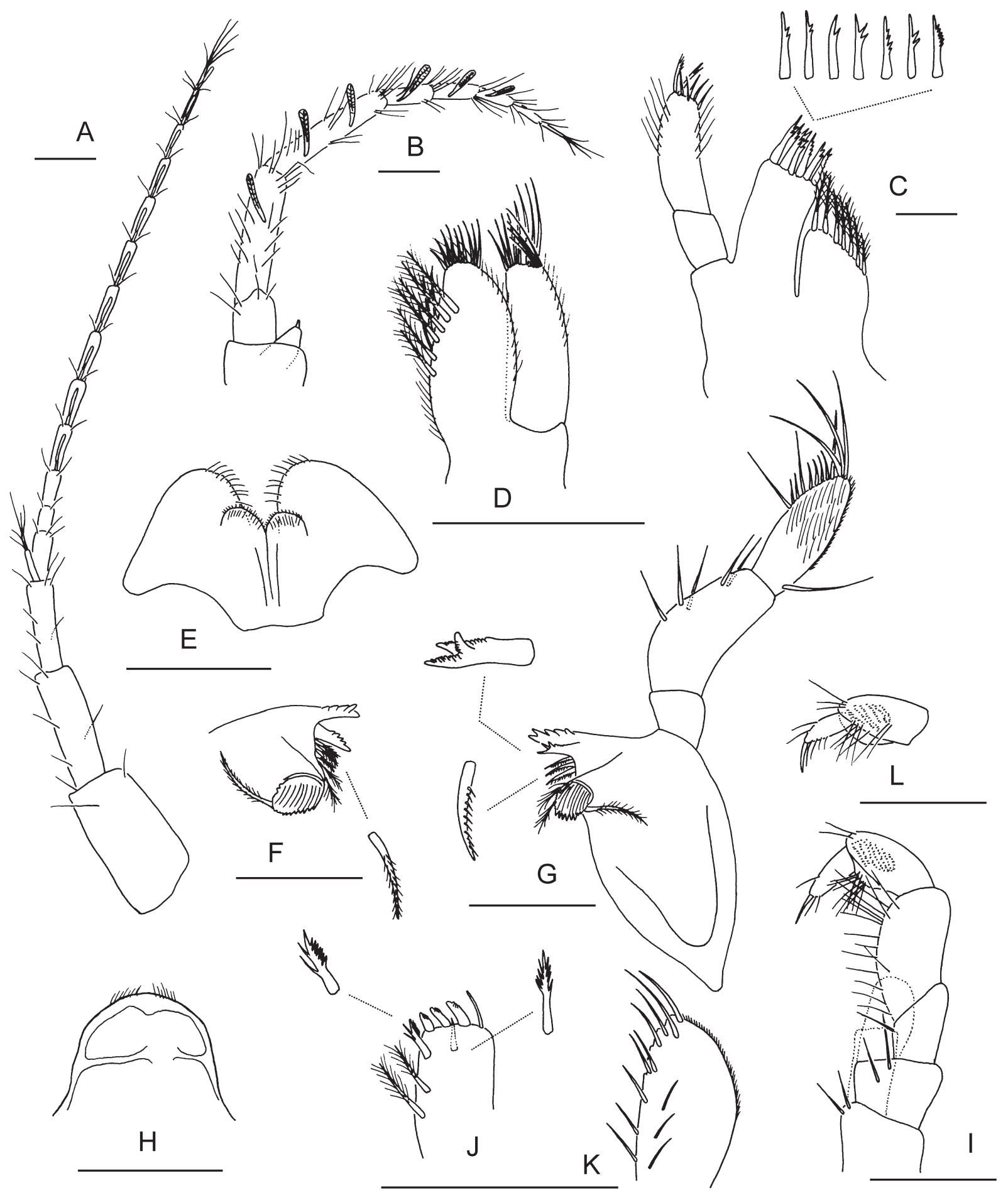

Fig. 4A-L. Synurella ambulans (F. Müller, 1846), Ō, $4.5 \mathrm{~mm}$, FENU X34906/Cr-1406, MO. A. Antenna 1. B. Antenna 2. C. Maxilla 1. D. Maxilla 2. E. Lower lip. F. Left mandible. G. Right mandible. H. Upper lip. I. Maxilliped. J. Maxilliped, inner plate. K. Maxilliped, outer plate. L. Distal part of maxilliped palp, female, $6.0 \mathrm{~mm}$, FENU X34906/Cr-1406, PP. Scale bars $0.2 \mathrm{~mm}$. 


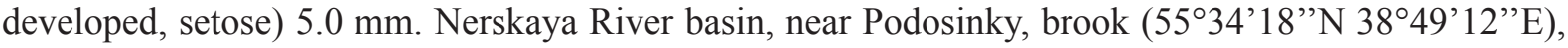
27 Aug. 2005, collected by D. Palatov; 2 우 (oöstegites developed, non-setose) $4.0 \mathrm{~mm}$ and $3.8 \mathrm{~mm}$,

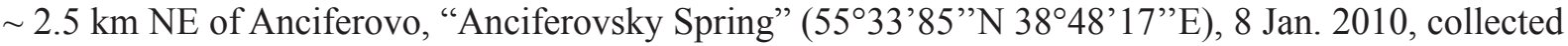

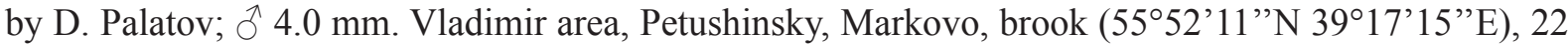
Apr. 2007, collected by D. Palatov.

\section{Additional material examined}

All specimens measured, partially dissected and stored in different vials [IBSS 17/2SD], ca. 82 우,

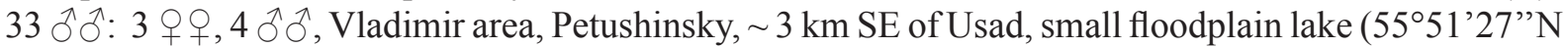
$39^{\circ} 08^{\prime} 76$ ”'E), 02 May 2009, collected by D. Palatov; 4 우, Gus-Khrustalny, near Shestimirovo, Buzha River basin, brook ( $55^{\circ} 27^{\prime} 09^{\prime \prime} N 40^{\circ} 13^{\prime} 68^{\prime \prime}$ ) $), 14$ May 1994, collected by M. Chertoprud and D. Palatov;

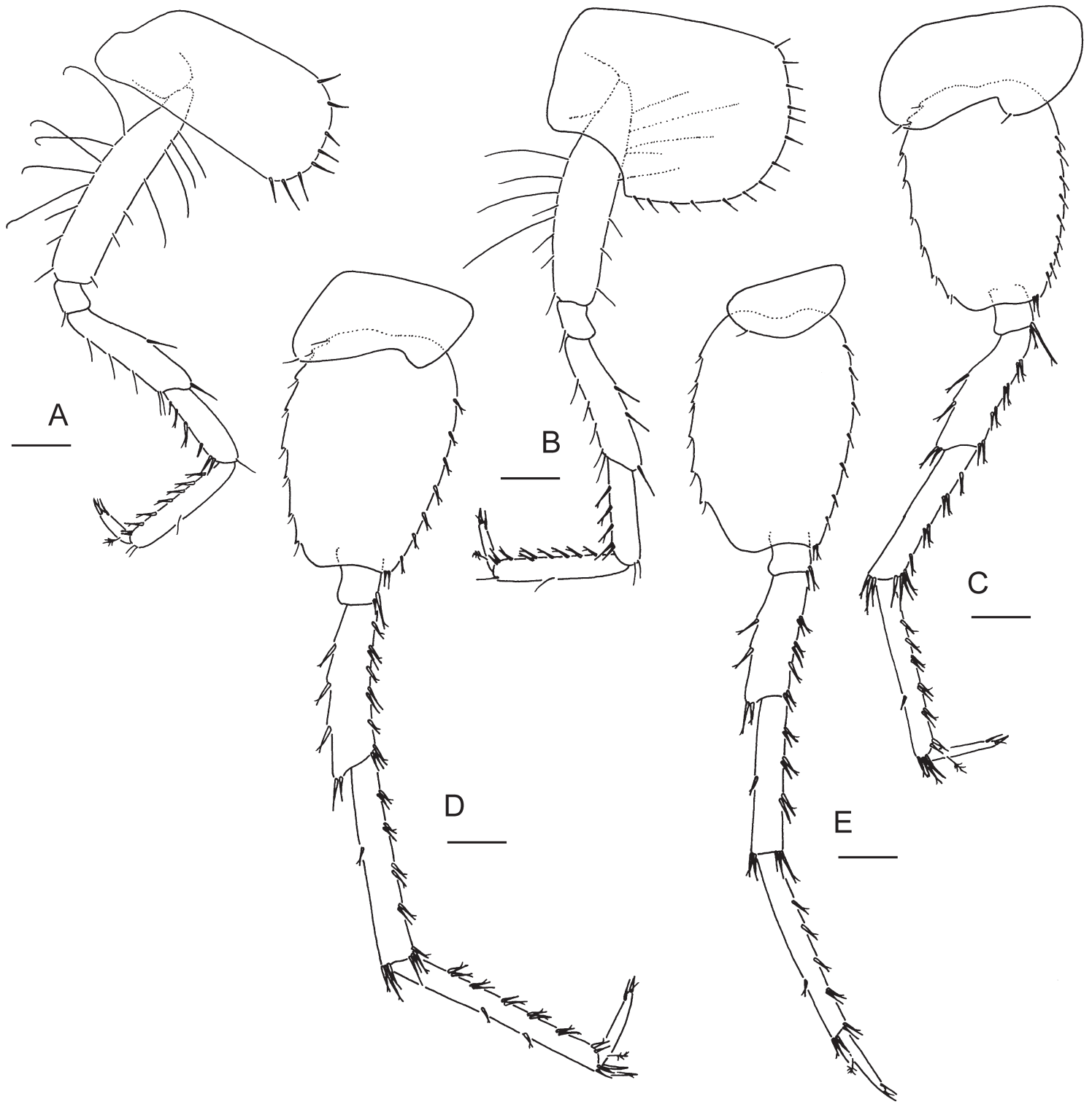

Fig. 5A-E. Synurella ambulans (F. Müller, 1846), O, 4.5 mm, FENU X34906/Cr-1406, MO. A. Pereopod 3. B. Pereopod 4. C. Pereopod 5. D. Pereopod 6. E. Pereopod 7. Scale bars $0.2 \mathrm{~mm}$. 


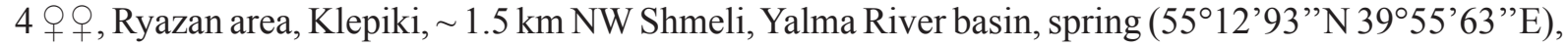
02 Oct. 2006, collected by M. Chertoprud and D. Palatov; 38 우: near Velikodvorye, Yalma River basin, springs $\left(55^{\circ} 12^{\prime} 46^{\prime \prime} \mathrm{N} 39^{\circ} 59^{\prime} 12^{\prime \prime} \mathrm{E}\right), 20$ Oct. 2006, collected by D. Palatov; ca. 50 우, Kaluga area, Ferzikovsky, 2 km E of Majakovsky, Oka River basin, spring (54'29'47'N 36²1'41'”E), 30 Apr. 2011, collected by D. Palatov; 5 우, $4 \hat{\jmath} \partial^{\lambda}$, Bryansk area, Navlinsky, near Dumcha, Dumcha River

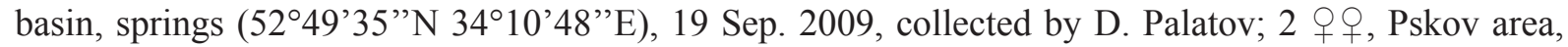
Pustoshkinsky, Velikaya River basin, 2 km W of Vysotskoe, brook (56 26'68'N 29²2'06'E), 16 Aug. 2010, collected by D. Palatov.

\section{Type locality}

Germany, Mecklenburg-Vorpommern, Greifswald (approx. 54 $5^{\circ} \mathrm{N}, 13^{\circ} 23^{\prime} \mathrm{E}$ ), ditches (F. Müller, 1846). Type material stored in the zoological collection of the Greifswald University (Zettler 1998: 57).

\section{Redescription}

\section{Male}

LENGTH. 4.5 mm, FENU X34906/Cr-1406.

Habitus. (Fig. 2B) Not stygomorphic.
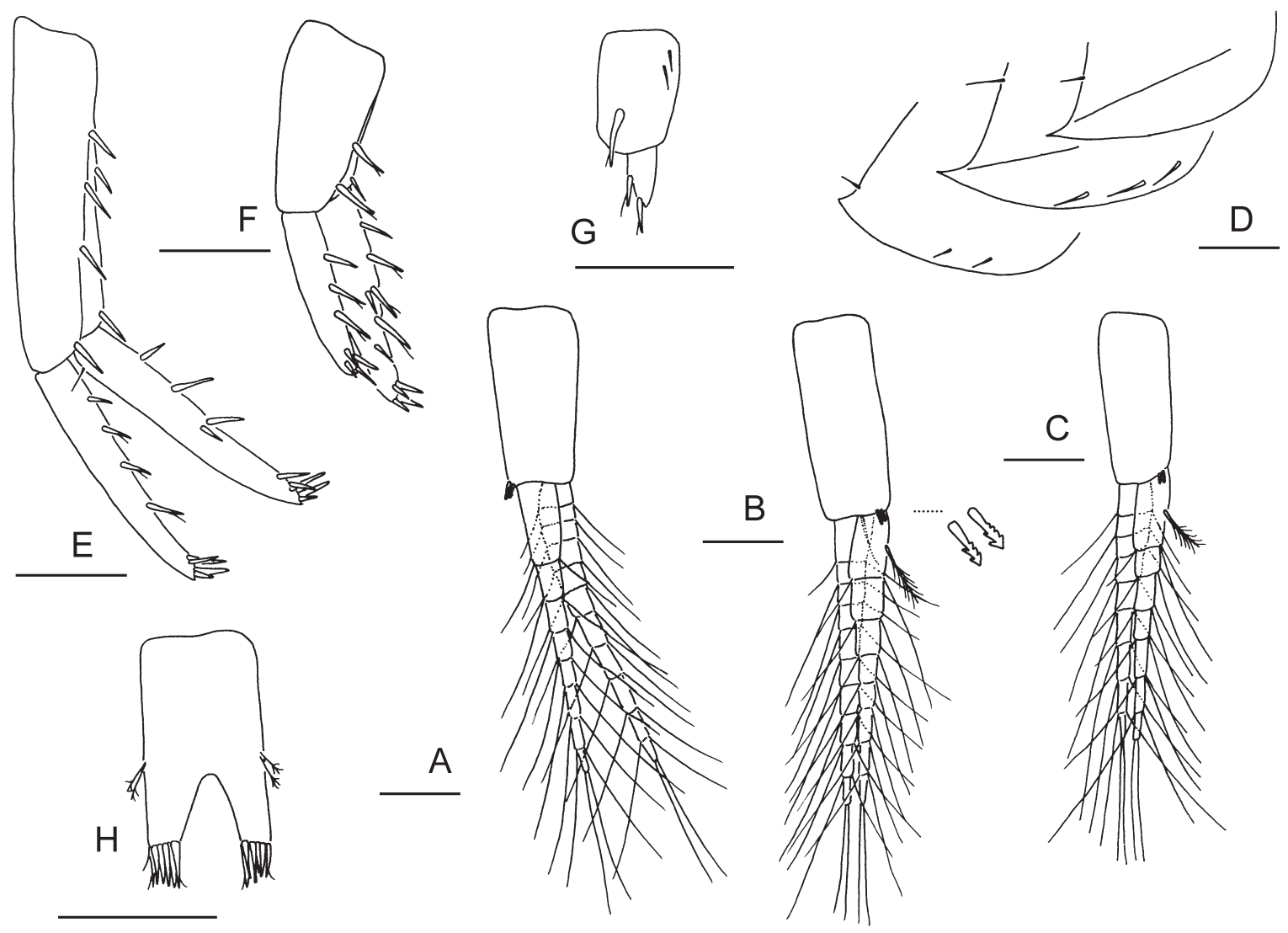

Fig. 6A-H. Synurella ambulans (F. Müller, 1846), đ̂, 4.5 mm, FENU X34906/Cr-1406, MO. A. Pleopod 1. B. Pleopod 2. C. Pleopod 3. D. Epimera 1-3. E. Uropod 1. F. Uropod 2. G. Uropod 3. H. Telson. Scale bars $0.2 \mathrm{~mm}$. 
BoDy. Slender with elongate appendages, color yellowish.

HeaD. Eyes (Figs 2B; 9) vestigial, black; yellow spot (Fig. 2A) located on the dorsal surface of the head between eyes characteristic for living specimens. Antenna 1 (Fig. 4A) 55\% length of body, 30\% longer than antenna 2; peduncular segments $1-3$ in length ratio 1:0.8:0.6; primary flagellum with 13 segments; aesthetascs present. Antenna 2 (Fig. 4B), peduncular segments 4 and 5 in lengths ratio 1:1; flagellum with 5 segments; calceoli present. Left mandible (Fig. 4F) incisor 5-dentate; lacinia mobilis 5-dentate; setal row with 3 serrate setae. Right mandible (Fig. 4G) incisor 5-dentate; lacinia mobilis trifurcate. Molar process (Fig. 4F, G) triturative, with accessory seta. Palp mandible (Fig. 4G) segment 2 slightly longer than segment 3; segment 3 with 1 A-seta, 2 C-setae, 6 D-setae and 4 E-setae. Lower lip (Fig. 4E), inner lobes present; mandibular process indistinct (broad). Maxilla 1 (Fig. 4C), inner plate with 7 plumose setae; outer plate with 7 serrate setae; palp segment 2 about $2 x$ longer than segment 1 . Maxilla 2 (Fig. 4D), inner plate with 6 plumose setae. Maxilliped (Fig. 4I-K) inner plate with 3 strong apical setae; outer plate broad. Foregut lateralia with 8 strong pectinate setae.

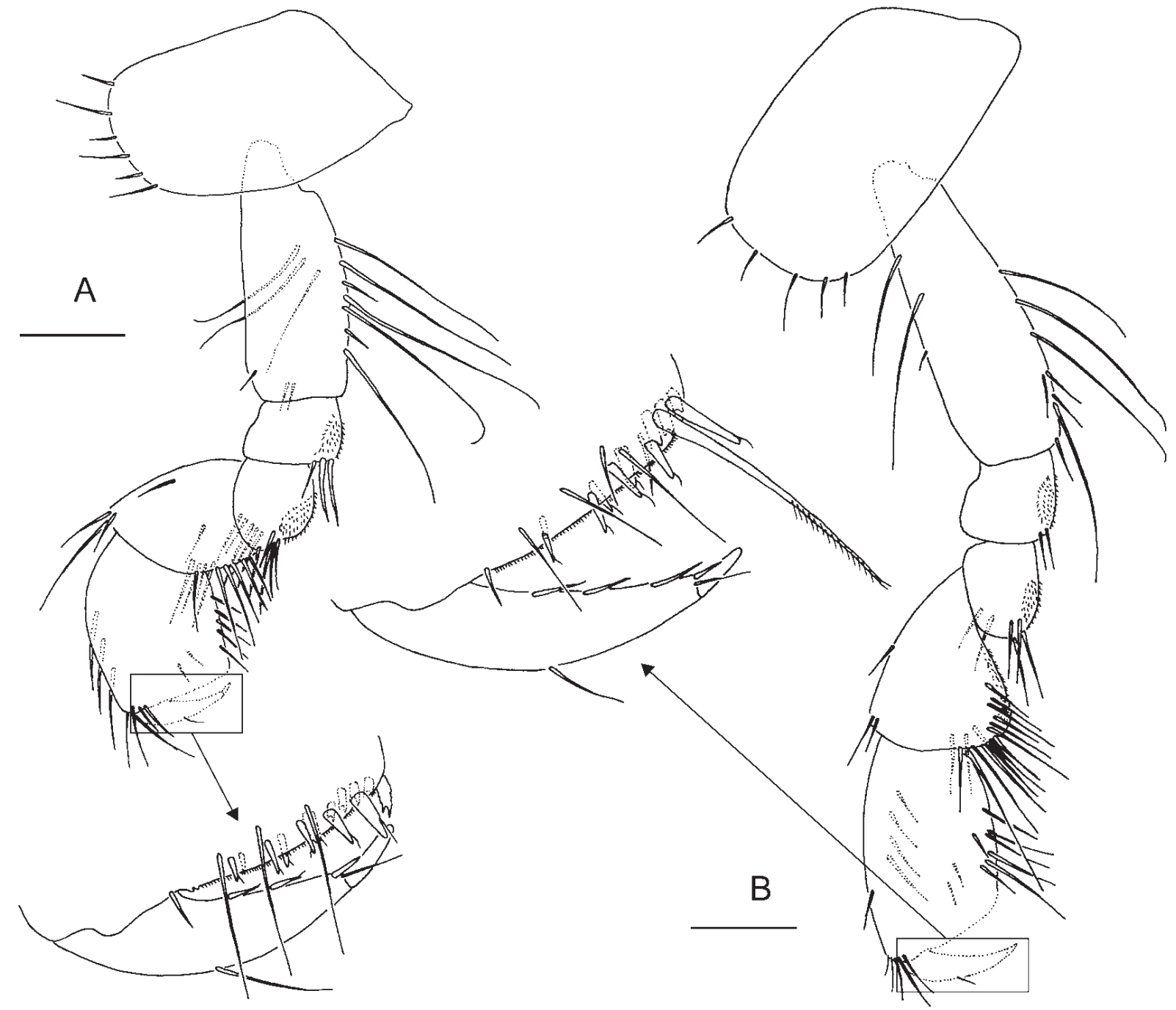

Fig. 7A-B. Synurella ambulans (F. Müller, 1846), + , $4.0 \mathrm{~mm}$, FENU X34906/Cr-1406, KF. A. Gnathopod 1. B. Gnathopod 2. Scale bars $0.2 \mathrm{~mm}$. 
Pereon. Gnathopod 1 (Fig. 3A), propodus palm beveled, defining angle distinct, palmar modified setae at defining angle present, palm with cutting margin smooth, palm with 19 simple strong setae in two rows; dactylus, inner margin smooth. Gnathopod 2 (Fig. 3B), propodus larger than gnathopod 1 propodus; palm distinctly beveled, defining angle distinct, palmar modified setae at defining angle present, palm with cutting margin smooth, palm with 24 simple strong setae in two rows; dactylus, inner margin smooth. Pereopod 6 longer than pereopod 7. Pereopods 5-7 (Fig. 5C-E) bases expanded, posterior margins with serration. Pereopods 3-7 (Fig. 5A-E) dactyli elongated, about 40-50\% length of corresponding propodi. Coxal gill 7 present. Paired median sternal gills on pereonite 2 and pereonite 3 . Single lateral sternal gills on pereonite 6 , pereonite 7 and pleonite 1 .

Pleon. Epimeron 1 (Fig. 6D), posteroventral corner acute or sub-acute, ventral margin unarmed. Epimera 2-3 (Fig. 6D), posteroventral corner acute or sub-acute, ventral margins armed. Pleopods 1-3 (Fig. 6AC), peduncular segments with 2 coupling setae (retinaculae). Uropod 1 (Fig. 6E), inner ramus $80 \%$ as long as peduncle, distal peduncular process absent. Uropod 2 (Fig. 6F) about $65 \%$ as long as uropod 1 ,

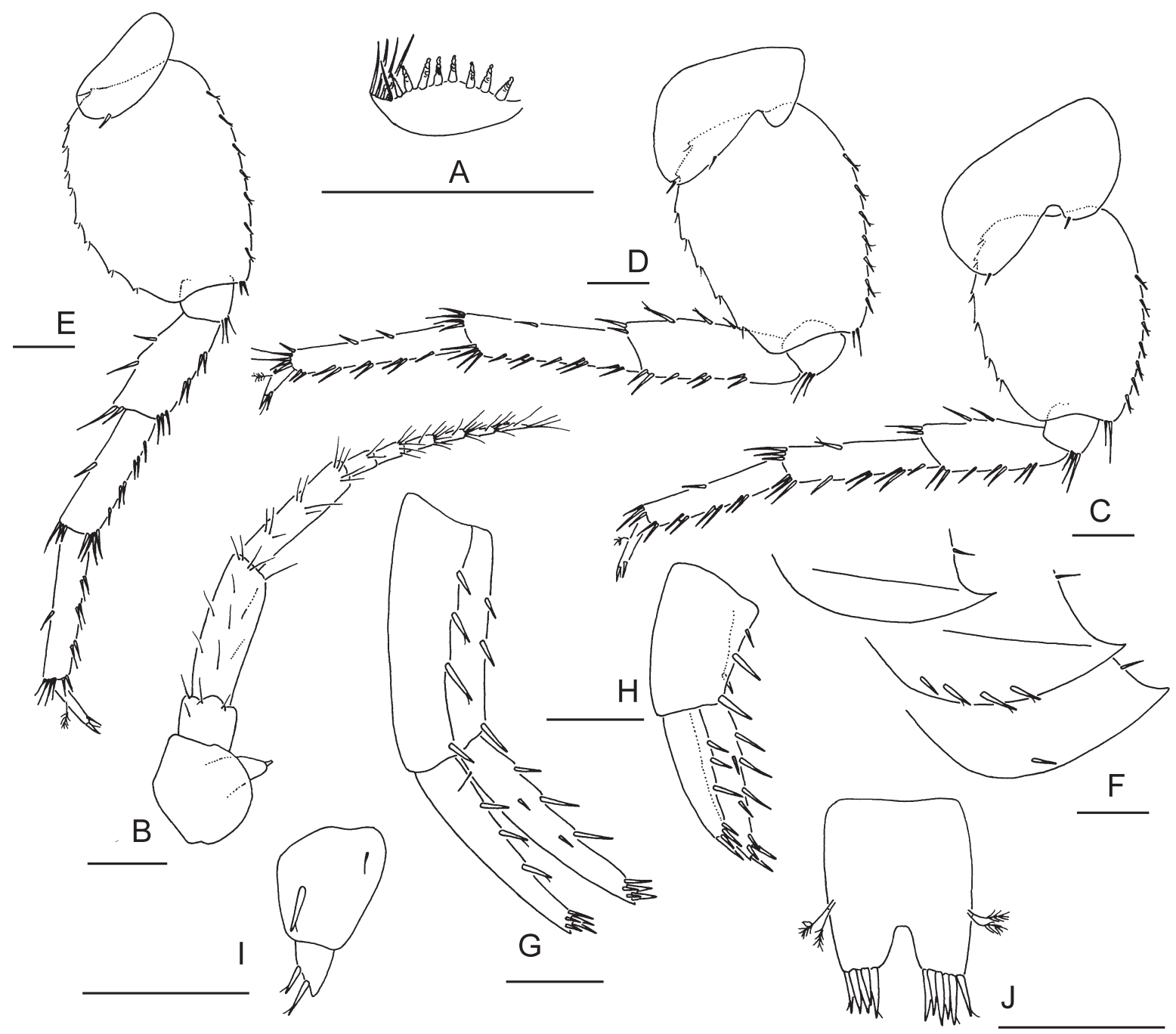

Fig. 8A-J. Synurella ambulans (F. Müller, 1846),, , 4.0 mm, FENU X34906/Cr-1406, KF. A. Lateralia. B. Antenna 2. C. Pereopod 5. D. Pereopod 6. E. Pereopod 7. F. Epimera 1-3. G. Uropod 1. H. Uropod 2. I. Uropod 3. J. Telson. Scale bars $0.2 \mathrm{~mm}$. 
peduncle shorter than inner ramus; inner ramus longer than outer ramus. Uropod 3 (Fig. 6G) uniramous, peduncle or/and lateral margin of ramus armed. Telson (Fig. $6 \mathrm{H}$ ) not tapered distally, rather elongate, $1.8 x$ longer than broad, about $10 \%$ longer than uropod 3 , apical margin cleft on $1 / 3$ of total length, with 6 strong notched setae on each lobe.

\section{Dimorphism}

\section{Female}

LENGTH. 5.5 mm, FENU X34906/Cr-1406), sexually dimorphic characters.

Body. (Fig. 2C) Stout, appendages shortened. Antenna $145 \%$ longer than antenna 2. Antenna 2 (Fig. 8B) flagellum with 6 segments; calceoli absent. Gnathopod 1 (Fig. 7A), propodus palm transverse or scarcely sub-transverse with cutting margin acanthaceous, palm with 8 simple strong setae in two rows; dactylus, inner margin with setae. Gnathopod 2 (Fig. 7B), propodus palm with cutting margin acanthaceous, palm with 7 simple strong setae in two rows; dactylus, inner margin with setae. Pereopods 3-7 (FIG. 8C-E), dactyli about $45-50 \%$ length of corresponding propodi. Uropod 1 (Fig. 8G), inner ramus as long as peduncle. Uropod 2 (Fig. 8H) about $60 \%$ as long as uropod 1. Telson (Fig. 8J) somewhat tapered distally, slightly elongate, $1.1 \mathrm{x}$ longer than broad, as long as uropod 3 . Oöstegites $2-5$ large, ovoid with long marginal setae.

\section{Variability}

Karaman (1974a) pointed out a significant variability in several morphological features for S. ambulans. However, in our analysis of individuals from the different parts of its range in Russia and Germany, we could not discover any significant variance in the shape of the lateral cephalic lobes, epimera, uropods, telson or bases of pereopod 7 (Fig. 9). In adults we observed elongation of the pereopod 7 bases and the presence of many robust setae on the lower edge of the epimera 2-3. Ommatidia were larger in young animals but their number was smaller than the one in adults. We also noted a slight variation in the length of the antenna $150-55 \%$ length of body and $40-45 \%$ longer than antenna 2 , and a considerable variation in the length of pereopods 3-7 dactyli (35-50\% length to corresponding propodi). The number of segments in the flagellum of antenna 1 equals 12-16. The specimens from Kholodny brook, near Yezerische Lake (Russia, Pskov area, Pustokshinsky) have a slightly different setation pattern of maxilliped palp segments 3 and 4 (Fig. 4L), but are otherwise indistinguishable.

\section{Remarks}

Borutzky (1929: 32) adduced several distinctive characters which, in his opinion, were sufficient to distinguish $S$. a. meschtscherica from $S$. a. ambulans: relative length of the both antennae, the stronger armament of mouthparts (viz., presence of scopiform bundles of setules on palpi of mandibles and maxilliped, presence of molar setae), armament of uropod 3 peduncle, the shape and armament of telson. After analyzing Borutzky's description, we are convinced that he has mixed details (p. 33) of males and females without explanation: the cited characters of the antenna 2 and the gnathopods belong to the female, while the telson characters are typical of the male. Moreover, Borutzky (loc. cit.) compared his own "mixed" description to the incomplete description by Schäferna (1922), who also depicted the female's telson without indication of gender. Borutzky (loc. cit.) evidently did not have Müller's (1846) original description at hand, in which the latter explains why he attributed subspecies status to his specimens.

The comparison of the material of $S$. ambulans from Russia, previously identified as Synurella meschtscherica, with that from Germany revealed no morphological differences between them. Comparison of the variability of the original samples with species descriptions by Müller (1846), Schäferna (1922) and Borutzky (1929) showed that both species are identical. We therefore consider 
Synurella ambulans meschtscherica Borutzky, 1929 a junior synonym of nominative S. ambulans (F. Müller, 1846).

The taxonomic status and geographic distribution of previously described forms of $S$. ambulans are in need of a substantial revision. In our opinion the complex classification of $S$. ambulans is caused by: 1) a poor first description of the species by F. Müller and 2) a relatively wide distribution of the genus in Europe. It is possible that $S$. ambulans, ranging widely in Europe and Asia with significant variability reported by some authors (see above), is actually a series of several cryptic species.

A few discrepancies were found in the comparison with the original description. Borutzky (loc. cit.) reported the body length of individuals within the range of 6-12 $\mathrm{mm}$ for mature specimens without an indication of the method of measurement. Our largest individual has a body length of $6.0 \mathrm{~mm}$. We have also studied the samples from Velikodvorskye springs of Ryazan area, previously also explored by Borutzky, where females up to $5.0 \mathrm{~mm}$ body length were found. Borutzky (1929: 32) also found a somewhat larger number of segments of the flagellum of the antenna 1, 18-24 (males) and 16-22 (females), and reported on eyeless individuals which are absent in our collections. However, the observed

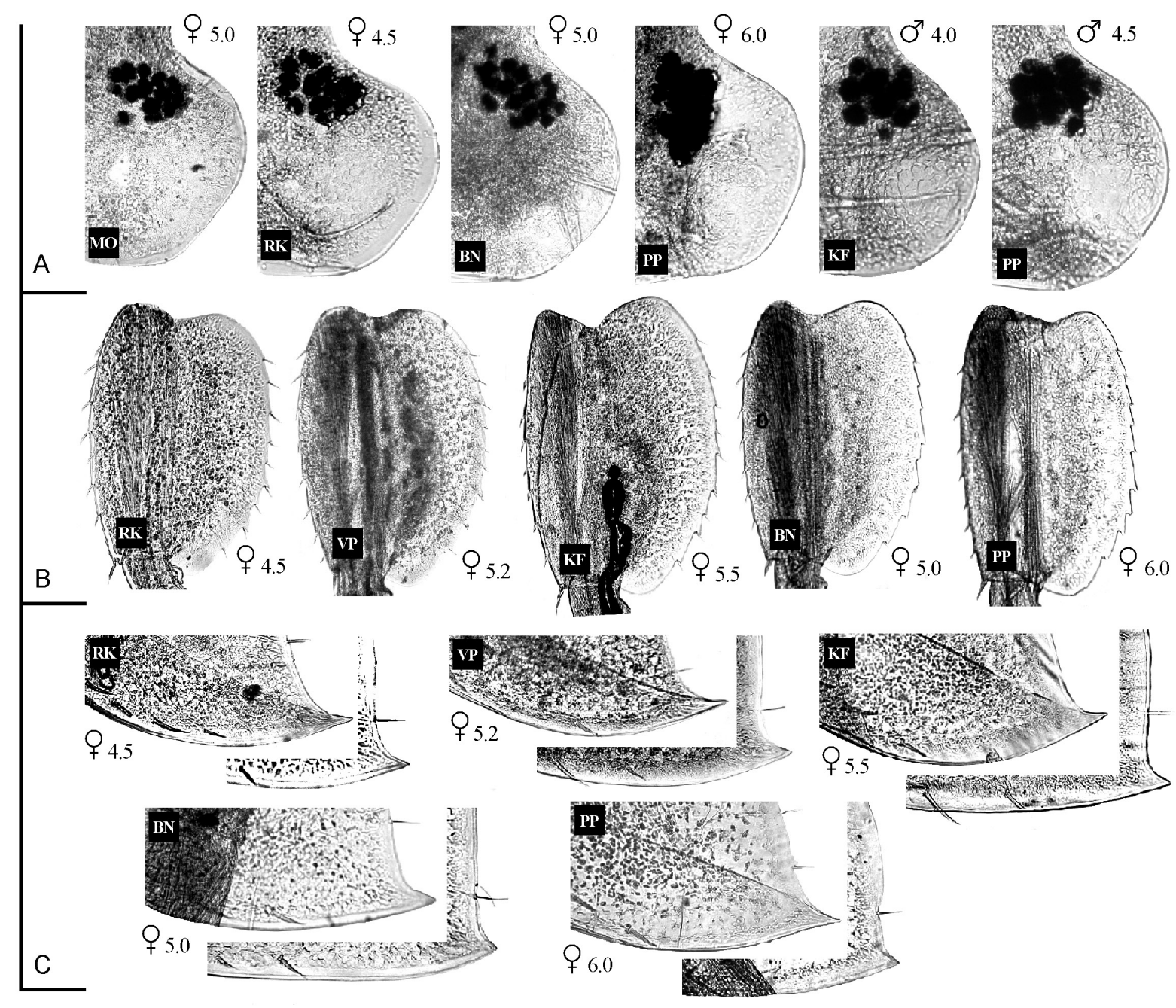

Fig. 9. Variability of (A) lateral cephalic lobe of Synurella ambulans (F. Müller, 1846) from different populations; (B) posterior margin of pereopod 7 basis; (C) epimera 2 and 3. (Digital Photomicrography). 
variability was not documented by this author, eyeless individuals were not described and had not been given a special status. The inaccuracy of Borutzky's description confirmed our doubts about the validity of $S$. meschtscherica and convinced us that only one form of Synurella is present in the Meschtschera Lowland.

\section{Distribution}

RUSSIA. Pskov area: Pustoshkinsky region. Vladimir area: Petushinsky and Gus-Khrustalny regions. Moscow area: Orekhovo-Zuevo, Egoryevsk and Shatura regions (Chertoprud 2006a, 2006b). Ryazan area, Klepiki (Borutzky 1927, 1929). Kaluga area: Ferzikovsky region. Bryansk area: Navlinsky region.

Although S. ambulans was found in extensive territories in West Russia, it was absent in a number of different springs (see map) with a rich crenophilous fauna. This mosaic distribution is apparently caused by environmental factors.

Synurella ambulans has been reported from many countries situated on the Great European Plain including Belgium (Boets et al. 2010), Germany (Heckes et al. 1996; Zettler 1998; Eggers \& Martens 2001), Poland (Konopacka \& Sobocinska 1992), Lithuania (Arbačiauskas 2008) and Belarus (Giginyak \& Moroz 2000).

\section{Ecology}

Stygophile, predominantly occupying semi-subterranean habitats. Biotopes mostly including wetlands, bogs, wetland areas of streams with swampy shores nearly everywhere overgrown with Alnus (see Borutzky 1929).

Synurella ambulans dwells in various springs, stagnant parts of the rivers and brooks connected with the ground outlets of subterranean waters, frequently associated with the asellid isopod Asellus aquaticus (Linnaeus, 1758). A characteristic features of all microhabitats are their stagnant or very slowly flowing waters, not exceeding $0.1 \mathrm{~m} / \mathrm{sec}$; a water temperature generally ranging between 2.0 and $16.0{ }^{\circ} \mathrm{C}$, a low oxygen concentration of 3.0-9.0 $\mathrm{O}^{2} \mathrm{mg} / \mathrm{l}$, a $\mathrm{pH}$ between 5.0-8.0 and low mineralization not higher than 197.5-353.1 mg/l (once 510.0 mg/l) (Nesemann et al. 1995; Giginyak \& Moroz 2000; Chertoprud 2006a). Springs are often covered with Lemna and Hydrocharis, or densely grown with Elodea and Fontinalis; bottoms are composed of detritus, sand, mud, snags and leaf litter. Dendrocometes paradoxus Stein, 1852 (Protozoa, Infusoria, Suctoria) is a common ectoparasite on the coxal gills of S. ambulans (see Taylor \& Sanders 2001).

The rare findings of $S$. ambulans in a number of a small floodplain lakes in the spring could be explained by the flood drift. However, most interesting is the accidental discovery (by DP) of a mass congestion of $S$. ambulans on the shallows of a large lake in the Velikaya River basin (Pskov area) in winter. It is possible that these crustaceans can survive adverse winter conditions by "warming up" near oozing from the bottom fontanels.

\section{Discussion}

\section{Comments on biogeography of Synurella species complex}

The biogeography of any group is closely linked with its phylogenetic relationships (Holsinger 1986), which in turn is related to a system of trustworthy diagnostic features. It is well-known that the taxonomy of the family Crangonyctidae is based largely on the structure of uropod 3, although the plasticity of this character had already been discussed (Bousfield 1983) and a recent molecular phylogeny confirms this (Hiwatari et al. 2011). The latest results of $18 \mathrm{~S}$ phylogeny also revealed an ancient radiation of Synurella with a paraphyletic relationship to the North American and European groups (Kornobis et al. 2011). 
Morphologically, the family Crangonyctidae is not homogeneous and can be tentatively divided into two groups of uneven size, but equivalent in terms of their "biogeographical weight". The first group includes taxa with the "free coxal plates 1-4" or commonly diagnosed as shallow coxae, when their width is greater than, or equal to, the height (this group includes: Bactrurus, Siberian Stygobromus and the majority of the North American Stygobromus). Two poorly described Eurasian species - Stygobromus apscheronicus (Derzhavin, 1945) and Stygobromus kazakhstanicus Kulkina, 1992 - occupy an intermediate position but they might belong to this group, because of their shallow coxal plates 3 and 4 . The second large group, however, consists of species with deep coxal plates and is distinguished by a coxal plate 4 with excavation. This group includes the North American and European Crangonyx, Synurella, Lyurella hyrcana Derzhavin, 1939, Stygonyx courtneyi Bousfield \& Holsinger, 1989, Amurocrangonyx arsenjevi (Derzhavin, 1927) and Palaeogammarus. The same character was used previously by Bousfield (1977) and Holsinger (1986) in a hypothesized phylogenetic relationship among Crangonyctidae. They ascribed a plesiomorphic state for the deep coxae and an apomorphic state for shallow or reduced coxae in overall size (see Holsinger 1986: 90). The front edge of the Crangonyctidae head is rather diverse in morphology (Holsinger 1977) and can be roundish (Fig. 9) or characterized by the presence of the inter-antennal lobe and inferior sinus. However, this feature apparently may not be appropriate for phylogenetic analyses, as we have observed non-uniform gradation from the roundish form ( $S$. ambulans) with intermediate form (S. derzhavini) to the expressed "sinusoidal form" (S. osellai) (see Sidorov et al. 2012). Meanwhile, we have concluded that both features of general body morphology are most important for separation of heterogeneous phyletic groups in future testing of biogeographic hypotheses.

\section{Taxonomic boundaries and eco-geographic distribution of Synurella ambulans}

Synurella ambulans has a large distribution in the lowlands of northern Europe, ranging from NW to NE Europe and possibly reaching the Black Sea area (Dedju 1967). Previously, from pieces of Baltic amber dated as far back as the Eocene, several forms of Synurella have been described as being closely related to the southern species $S$. intermedia, because of the somewhat extended pereopod 7 bases and the non-acute posteroventral epimeral corners (see Coleman 2004: 3). Perhaps the northern distribution of $S$. ambulans may be a relatively recent phenomenon, after the retreat of the glaciers in the early Holocene. However, we do not know the southern and western boundary of the distribution of this species. The findings of $S$. ambulans in Southern Europe and Asia Minor indicate that its range is discontinuous. This assumption is questionable and requires additional verification. In our view, all references to S. ambulans in Asia Minor (Ruffo 1974; Karaman 2003; Ustaoğlu et al. 2004) as well as in Southern Europe (Bonacina et al. 1992; Stoch \& Dolce 1994; Pezzoli 2010) are ambiguous and should be recompared carefully with $S$. ambulans from other areas.

Synurella ambulans is absent from a number of intact springs, unaffected by anthropogenic stress (Fig. 1). These springs were almost always rich in crenophilous fauna. As noted by Giginyak \& Moroz (2000), Synurella ambulans inhabits springs with water close to melt water in physical and chemical properties. The natural tolerance of the studied amphipod specimens of $S$. ambulans was limited to low concentration of oxygen and mineralization (see Giginyak \& Moroz 2000: 82). Previously, a similar relationship between life in springs and low water hardness of $1.2-1.6^{\circ} \mathrm{dGh}(=214.1-285.6 \mathrm{mg} / \mathrm{l})$ was noted for the Far Eastern Amurocrangonyx (Birstein \& Levanidov 1952). It is interesting that S. ambulans apparently has a feature that can distinguish it from the other species of the genus, namely a yellowish spot (url: www.biospeleo.ru/S ambulans.htm) which is the hypertrophied digestive gland. Previously, the observation of a yellowish (orange) spot for the species was mentioned by Müller (1846), Stebbing (1906), Borutzky (1929) and Boets et al. (2010). The hypertrophied digestive gland (HDG) is characteristic also of several deep-sea marine amphipods, e.g. Eurythenes gryllus Lichtenstein, 1822 where it performs the leading role in the metabolic response of the defense antioxidant system (Camus \& Gulliksen 2004). In subterranean amphipods the HDG has also been observed in Amurocrangonyx. 


\section{Acknowledgements}

We thank Mikhail Chertoprud (Moscow State University) for collection and forwarding material to us and Oliver Coleman (Humboldt University, Berlin) for loan of specimens of Synurella ambulans from the Museum für Naturkunde in Berlin. Both loans made this study possible. We would also like to thank Rudy Jocqué (Royal Museum for Central Africa, Tervuren), Kristiaan Hoedemakers (Royal Belgian Institute of Natural Sciences, Brussels), Oliver Coleman and an anonymous reviewer for critically reading and commenting on the manuscript, largely improving content and style of the paper.

The study was funded with partial financial support of the Russian Foundation for Basic Research grant 09-04-98544 and of the Presidium of FEBRAS grants 11-III-B-06-098 and 12-I-П30-01.

\section{References}

Alexandrov B., Boltachev A., Kharchenko T., Lyashenko A., Son M., Tsarenko P. \& Zhukinsky V. 2007. Trends of aquatic alien species invasions in Ukraine. Aquatic Invasions 2 (3): 215-242. http://dx.doi. org/10.3391/ai.2007.2.3.8

Arbačiauskas K. 2008. Synurella ambulans (F. Müller, 1846), a new native amphipod species of Lithuanian waters. Acta Zoologica Lituanica 18 (1): 66-68. http://dx.doi.org/10.2478/v10043-008-0006-z

Barnard J.L. 1958. Index to the families, genera and species of the gammaridean Amphipoda (Crustacea). Occasional Paper. No. 19. Allan Hancock Foundation Publications, Los Angeles.

Barnard J.L. \& Barnard C.M. 1983. Freshwater Amphipoda of the World. Vols. 1, 2. Mt. Vernon, Hayfield Associates, Virginia.

Birstein J.A. 1948. The size and distribution of the genus Synurella (Crustacea, Amphipoda). Doklady Akademiy Nauk SSSR 60 (4): 701-704. [in Russian]

Birstein J.A., Levanidov V.Ya. 1952. A new species of subterranean asellid from the Ussury basin. Doklady Akademiy Nauk SSSR 84 (5): 1081-1084. [In Russian]

Boets P., Lock K. \& Goethals P.L.M. 2010. First record of Synurella ambulans (Müller, 1846) (Amphipoda: Crangonictidae) in Belgium. Belgian Journal of Zoology 140 (2): 242-243.

Bonacina C., Bonomi G. \& Pasteris A. 1992. Some remarks on the macrobenthos community of the profundal zone of the large Italian lakes. Memorie dell'Istituto Italiano di Idrobiologia dott. Marco De Marchi 50: 79-146.

Borutzky E.W. 1927. On the occurrence of the amphipod Synurella ambulans in Russia. Annals and Magazine of Natural History. Series 920 (115): 63-66.

Borutzky E.W. 1929. Crustacea-Malacostraca der Gewässer der Meschtschera-Niederung (Gouv. Rjasan, Zentralrussland). Arbeiten der Biologischen Station zu Kossino 9: 29-39. [in Russian]

Bousfield E.L. 1977. A new look at the systematics of gammaroidean amphipods of the world. Crustaceana. Suppl. 4: 282-316.

Bousfield E.L. 1983. An updated phyletic classification and palaeohistory of the Amphipoda. In: Schram F.R. (ed.) Crustacean Phylogeny: 257-277. A.A Balkema, Rotterdam.

Camus L. \& Gulliksen B. 2004. Total oxyradical scavenging capacity of the deep-sea amphipod Eurythenes gryllus. Marine Environmental Research 58: 615-618. http://dx.doi.org/10.1016/j. marenvres.2004.03.051

Chertoprud M.V. 2006a. Fauna of scuds (Crustacea, Amphipoda) of Moscow Region. Inland Water Biology 67 (4): 17-21. [in Russian] 
Chertoprud M.V. 2006b. Spring macrobenthos communities of the Moscow province. Zhurnal Obshchei Biologii 67 (5): 376-384. [in Russian]

Coleman C.O. 2004. Aquatic amphipods (Crustacea: Amphipoda: Crangonyctidae) in three pieces of Baltic amber. Organisms, Diversity \& Evolution 4, Suppl. 3: 1-7.

Dallwitz M. 2005. Overview of the DELTA System. Available from: http://delta-intkey.com/www/overview. $\underline{\mathrm{htm}}$ [accessed 28 Nov. 2009]

Dedju J. 1967. Amphipods and mysids of basins of the rivers Dniester and Prut. Nauka Press, Moscow. [in Russian]

Eggers T.O. \& Martens A. 2001. A key to the freshwater Amphipoda (Crustacea) of Germany. Lauterbornia 42: 1-68.

Giginyak Yu.G. \& Moroz M.D. 2000. Ecological and biotopical features of the relict amphipod Synurella ambulans from springs of Belarus. Doklady of the National Academy of Sciences of Belarus 44 (5): 81-83. [in Russian]

Gorodkov K.B. 1961. The simplest microprojector for drawing insects. Entomological Review 40: 936939. [in Russian]

Heckes U., Hess M. \& Burmeister E.G. 1996. Ein Vorkommen von Synurella ambulans F. Müller 1846 (Amphipoda: Crangonyctidae) in Südbayern. Lauterbornia 25: 95-105.

Hiwatari T., Shinotsuka Y., Morino H. \& Kohata, K. 2011. Phylogenetic relationships among families and genera of talitroidean amphipods (Crustacea) deduced from 28S rRNA gene sequences. Biogeography 13: $1-8$.

Holsinger J.R. 1974. Systematics of the subterranean amphipod genus Stygobromus (Gammaridae). Part I: Species of the western United States. Smithsonian Contributions to Zoology 160: 1-63.

Holsinger J.R. 1977. A review of the systematics of the holarctic amphipod family Crangonyctidae. Crustaceana, Suppl. 4: 244-281.

Holsinger J.R. 1986. Zoogeographic patterns of North American subterranean amphipod crustaceans. In: Gore R.H. \& Heck K.L. (eds) Crustacean Biogeography. Crustacean Issues: 85-106. Balkema, Rotterdam.

Jarocki J. \& Krzysik S.M. 1924. Materialien zur Morphologie und Ökologie von Synurella ambulans (Fr. Muller). Bulletin international de l'Académie polonaise des sciences et des lettres. Classe des sciences mathématiques et naturelles. Série B: Sciences naturelles 7: 555-586.

Karaman G.S. 1970. Kritische Bemerkungen über Echinogammarus acarinatus (S. Kar. 1931) und Echinogammarus stocki n. sp. Poljoprivreda i Šumarstvo, Titograd 16: 45-66.

Karaman G.S. 1974a. Genus Synurella Wrzes. in Yugoslavia with remarks on its all world known species, their synonymy, bibliography and distribution (fam. Gammaridae). Poljoprivreda $i$ Šumarstvo, Titograd 20: 83-133.

Karaman G.S. 1974b. Revision of the genus Stygobromus Cope, 1872 (Fam. Gammaridae) from North America. Glasnik Republickog Zavoda za Zastitu Prirode i Prirodnjackog Muzeja, Titograd 7: 97-125.

Karaman G.S. 1990. New and interesting species of the genus Synurella Wrzes. 1877 (Fam. Crangonyctidae) from Soviet Union (U.S.S.R.). Glasnik Republickog Zavoda za Zastitu Prirode i Prirodnjackog Muzeja, Titograd 23: 25-50. 
Karaman G.S. 2003. New data on some gammaridean amphipods (Amphipoda, Gammaridea) from Palearctic. Glasnik of the Section of Natural Sciences Montenegrin Academy of Sciences and Arts 15: 20-37.

Ketelaars H.A.M. 2004. Chapter 13. Range extensions of Ponto-Caspian aquatic invertebrates in Continental Europe. In: Dumont H., Shiganova T.A. \& Niemann U. (eds) Aquatic Invasions in the Black, Caspian, and Mediterranean Sea: 209-236. Kluwer Academic Publishers, Dordrecht.

Konopacka A. \& Sobocinska V. 1992. Uwagi na temat wystepowania skorupiaka Synurella ambulans (Müll.) (Amphipoda, Crangonyctidae) w Polsce. Przeglad Zoologiczny 36: 123-131.

Kontschán J. 2001. Data of crustacean fauna (Crustacea: Amphipoda et Isopoda et Decapoda) of Majk (North-Vértes Mts.). Folia historico naturalia musei Matrensis 25: 65-68.

Kornobis E., Pálsson S., Sidorov D.A., Holsinger J.R. \& Kristjánsson B.K. 2011. Molecular taxonomy and phylogenetic affinities of two groundwater amphipods, Crangonyx islandicus and Crymostygius thingvallensis, endemic to Iceland. Molecular Phylogenetics \& Evolution 58: 527-539. http://dx.doi. org/10.1016/j.ympev.2010.12.010

Martynov A. 1931. Note on the fresh-water Amphipoda and Isopoda of northern Yakutia. Annuaire du Musée Zoologique de l'Académie des Sciences de l'URSS 32: 523-543.

Müller F. 1846. Ueber Gammarus ambulans, neue Art. Archiv für Naturgeschichte 12 (1): 296-300.

Muskó I.B. 1994. Occurrence of Amphipoda in Hungary since 1853. Crustaceana 66 (2): 144-152.

Nesemann H. 1993. Zur Verbreitung von Niphargus (Phaenogammarus) Dudich 1941 und Synurella Wrześniowski 1877 in der ungarischen Tiefebene (Crustacea, Amphipoda). Lauterbornia 13: 61-71.

Nesemann H., Pöckl M. \& Wittmann K.J. 1995. Distribution of epigean Malacostraca in the middle and upper Danube (Hungary, Austria, Germany). Miscellanea Zoologica Hungarica 10: 49-68.

Pezzoli E. 2010. Notes on new or rare taxa of Crustaceans and Molluscs from a "fontanile" in Arzago d'Adda, Bergamo, Italy (Crustacea, Mollusca). Biodiversity Journal 1 (1/4): 45-55.

Ruffo S. 1974. II genere Synurella Wrzesn. in Anatolia, descrizione di una nuova specie e considerazioni su Lyurella hyrcana Dersh. (Crustacea Amphipoda, Gammaridae). Memorie Del Museo Civico Di Storia Naturale Di Verona. 1 serie 20: 389-404.

Schäferna K. 1922. Amphipoda balcanica, spolu s poznámkami o jiných sladkovodních Amphipodech. Věstnik Královske České společnosti Náuk 2: 1-111.

Schellenberg A. 1942. Krebstiere oder Crustacea IV: Flohkrebse oder Amphipoda. In: Dahl F. (ed.) Die Tierwelt Deutschlands 40: 1-252. Verlag Gustav Fisher, Jena.

Sidorov D.A., Pankov N.N. \& Holsinger J.R. 2012. Distribution and ecology of the subterranean amphipod Crangonyx chlebnikovi Borutzky, 1928 (Crustacea: Crangonyctidae), with lectotype designation and comments on morphology of the lateral cephalic lobe. Arthropoda Selecta 21 (2): 149-160.

Starobogatov J.I. 1995. Amphipoda. In: Tsalolikhin S.J. (ed.) Key to freshwater invertebrates of Russia and adjacent lands: 184-206. ZINRAS, St. Petersburg. [in Russian]

Stebbing T.R.R. 1906. Amphipoda I. Gammaridea. In: Schulze F.E. (ed.) Das Tierreich: 1-806. R. Friedländer und Sohn, Berlin.

Stoch F. \& Dolce S. 1994. Progetto Timavo: risultati delle indagini sulla fauna delle acque sotterranee. Atti e Memorie Commissione Grotte "E. Boegan", Trieste 31: 59-71.

Straškraba M. 1962. Amphipoden der Tschechoslowakei nach den Sammlungen von Prof. Hrabe. I. Vestnik Československé Zoologické Společnosti 26 (2): 117-145. 
Straškraba M. 1967. Amphipoda. In: Lilies J. (ed.) Limnofauna Europae: 202-209. Gustav Fischer Verlag, Stuttgart.

Taylor W.D. \& Sanders R.W. 2001. Protozoa. In: Thorp J.H. \& Covich A.P. (eds) Ecology and Classification of North American Freshwater Invertebrates: 43-96. Academic Press, London.

Ustaoğlu M.R., Balik S. \& Özbek M. 2004. Contributions to the knowledge of Malacostraca (Crustacea) fauna of the Taurus Mountains district (Southern Anatolia). Turkish Journal of Zoology 28: 91-94.

Watling L. 1989. A classification system for crustacean setae based on the homology concept. Crustacean Issues 6: 15-26.

Zettler M.L. 1998. Zur Verbreitung der Malacostraca (Crustacea) in den Binnen- und Küstengewässern von Mecklenburg-Vorpommern. Lauterbornia 32: 49-65.

Manuscript received: 28 April 2012

Manuscript accepted: 30 July 2012

Published on: 27 September 2012

Topic editor: Rudy Jocqué

In compliance with the $I C Z N$, printed versions of all papers are deposited in the libraries of the institutes that are members of the EJT consortium: Muséum National d'Histoire Naturelle, Paris, France; National Botanic Garden of Belgium, Meise, Belgium; Royal Museum for Central Africa, Tervuren, Belgium; Natural History Museum, London, United Kingdom; Royal Belgian Institute of Natural Sciences, Brussels, Belgium; Natural History Museum of Denmark, Copenhagen, Denmark. 